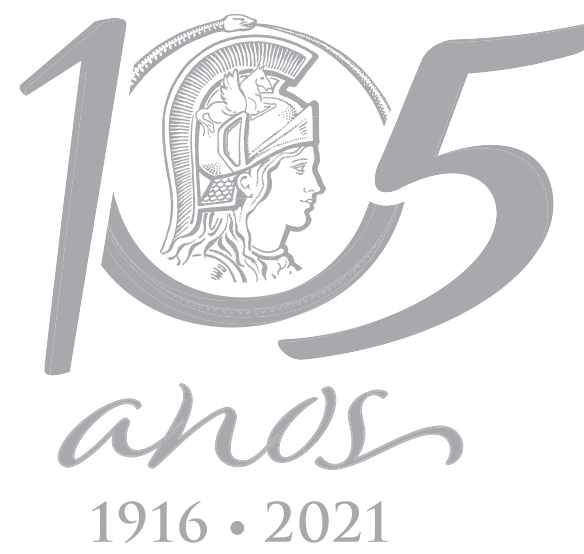

\title{
Major triterpenoids from Eucalyptus tereticornis have enhanced beneficial effects in cellular models when mixed with minor compounds present in raw extract
}

\author{
LAURA I. BETANCUR, DIANA L. MUÑOZ, ALIS GUILLEN, LUIS F. ECHEVERRI, \\ NORMAN BALCAZAR \& SERGIO ACÍN
}

\begin{abstract}
Obesity is a major risk factor for type 2 diabetes mellitus development and is characterized by an abnormal expansion of adipose tissue and low-grade chronic inflammation that contribute to insulin resistance. Although there are multiple treatments, most therapies can produce undesirable side effects and therefore, new and effective treatments with fewer side effects are necessary. Previously, we demonstrated that a natural extract from the leaves of Eucalyptus tereticornis (OBE100) has anti-inflammatory, hypoglycemic and hypolipidemic activities. The major compounds identified in OBE100 were three pentacyclic triterpenoids, ursolic acid, oleanolic acid, and ursolic acid lactone. Triterpenoids have shown multiples biological activities. This current study compared the biological effect produced by OBE100 with five different reconstituted mixtures of these triterpenoids. Different cell lines were used to evaluate cytotoxicity, reactive oxygen species production, inflammatory cytokine expression, glucose uptake induction, leptin and adiponectin expression, and lipid accumulation. OBE100 treatment was the most efficacious and none of the formulated triterpenoid mixtures significantly improved on this. Moreover, OBE100 was less toxic and reduced reactive oxygen species production. Our study showed that the proven beneficial properties of triterpenoids may be enhanced due to the interaction with minor secondary metabolites present in the natural extract improving their anti-inflammatory properties.
\end{abstract}

Key words: Eucalyptus tereticornis, obesity, triterpenoids, type 2 diabetes mellitus.

\section{INTRODUCTION}

According to a 2018 World Health Organization report, worldwide obesity has nearly tripled since 1975. Over 1.9 billion people are now obese or overweight, including 340 million children and adolescents (WHO 2018). Obesity is accompanied by low-grade inflammation that explains metabolic complications linked to increases in weight. Inflammation may play a causative role in generating insulin resistance, defective insulin secretion and disruption of other aspects of energy homeostasis in type 2 diabetes mellitus (T2DM) development (Donath \& Shoelson 2011, Saltiel \& Olefsky 2017).

Reducing body weight using pharmacotherapy may provide benefits by lowering the risk of obesity-associated comorbidities; however, many weight-loss therapies present serious adverse effects and only a few are commercially available (Krentz et al. 2016). Antihyperglycemic agents have similar problems, resulting in side effects or nonadherence (Polonsky \& Henry 2016). Thus, identifying novel therapeutic agents may benefit the large number of patients suffering from 
T2DM. One goal is to break the links between inflammation and diabetes using a combined administration of different pharmacologically active metabolites.

Secondary metabolites of plants have been used by traditional medicine to treat a wide spectrum of diseases (Petrovska 2012). Plants are an abundant natural source of potential new medicines and a valuable material in the development of new and improved obesity and T2DM treatments. Eucalyptus tereticornis Sm. (Myrtaceae) (Eu) is used in traditional medicine to control diabetes. We previously showed that Eu extracts had hypoglycemic/antidiabetic, hypolipidemic, and anti-inflammatory effects in cellular and mouse models (Ceballos et al. 2018, Guillén et al. 2015). An extract from Eu leaves, named OBE100, contains three triterpenoids as main molecules: $47.6 \%$ ursolic acid (UA); $14.1 \%$ oleanolic acid (OA); and $16.3 \%$ ursolic acid lactone (UAL). OBE100 has an effect on different cell types and can reverse immunometabolic changes associated with obesity (Ceballos et al. 2018).

UA and OA are pentacyclic triterpenoids, considered as anti-obesity and hypoglycemic agents. UA is a natural compound isolated from leaves, flowers, and fruits of various medicinal plants and exhibits anti-inflammatory, antioxidant, anticarcinogenic, anti-obesity, antidiabetic, cardioprotective, neuroprotective, and hepatoprotective effects (Katashima et al. 2017, Seo et al. 2018). OA is also widely found in plants, fruits, and vegetables, and has been attributed to antioxidant, antitumor, antiinflammatory, antidiabetic and antimicrobial pharmacological activities (Ayeleso et al. 2017, Gamede et al. 2018). The mechanisms of action of these triterpenoids are due to a reduction of glucose absorption, inhibition of endogenous glucose production, increase in insulin sensitivity, improvement of lipid homeostasis, and promotion of body-weight regulation (Nazaruk \& Borzym-Kluczyk 2015, Silva et al. 2016). UAL is a less studied triterpenoid found in plants but is known to have anti-inflammatory effects (Maurya et al. 2012).

Interestingly, triterpenoids used in combination with other molecules have an improved beneficial effect. OA and UA have been reported to work synergistically with metformin therapy in lowering blood glucose and improving insulin sensitivity and renal and hepatic function (Mourya et al. 2018, Wang et al. 2015). In addition, mixtures of UA and loganin, an iridoid glycoside, have synergistic therapeutic action with diabetes (He et al. 2016). We previously demonstrated that the mixture of these three different triterpenoids has a more powerful effect in reducing immunometabolic abnormalities than a purified extract enriched in UA and OA (Ceballos et al. 2018). In this study, in order to get the best combination of molecules for a potential phytopharmaceutical drug for treating T2DM, cellular models were used to investigate if different reconstituted mixtures of $U A, O A$, and $U A L$, at different ratios, may enhance the anti-inflammatory, hypolipidemic, and hypoglycemic effect or reduce the natural extract cytotoxicity, when these three molecules are mixed with unknown minor compounds.

\section{MATERIALS AND METHODS}

\section{Triterpenoid mixtures preparation}

E. tereticornis leaves were collected in Valledupar (Colombia) in 2011. A specimen was deposited in the Herbarium of the University of Antioquia with \# 178511. OBE100 was extracted as previously described (Ceballos et al. 2018). Briefly, the dried leaves from E. tereticornis, were extracted by a liquid-liquid separation with hexane: methanol: water 4:3:1(v/v); the organic phase was collected and vacuum filtered. The precipitate formed was 
collected, stored, and called OBE100. In order to prepare artificial mixtures of triterpenoids, $U A$ and $O A$ were acquired commercially from Sigma-Aldrich (St. Louis, Mo, USA). UAL is not available commercially and it was obtained from Eu leaves, using repeated preparative thin layer chromatography, as previously described by Ceballos et al. 2018. We designed 5 different mixtures of triterpenoids with the same total amount of triterpenoids present in OBE100 (M1-M5). (Table I and Supplementary Material Tables SI-SIII). M1 contains the same proportions of triterpenoids present in OBE100, with UA as the main molecule. M2 contains UAL as the main molecule. M3 contains $O A$ as the main molecule. M4 maintains UA and OA proportions present in OBE100 with half the concentration, and M5 contains the same proportion of each triterpenoid.

\section{Cell cultures}

J774A.1 (TIB-67TM) mouse macrophage cells, C2C12 (ATCCCRL-1772) mouse muscle cells and 3T3-L1 (CL-173 ${ }^{\mathrm{TM}}$ ) mouse fibroblast cells, were purchased from ATCC (Manassas, VA, USA). Cells were cultured in Dulbecco's Modified Eagle's Medium
(DMEM) with 10\% fetal bovine serum (FBS), $2 \mathrm{mM}$ glutamine and 1\% penicillin/streptomycin (Sigma- Aldrich, St. Louis, Mo, USA) at $37^{\circ} \mathrm{C}$ and $5 \% \mathrm{CO}_{2}$. J774A.1 cells were cultured with $5.5 \mathrm{mM}$ glucose (Growth medium 1 - GM1); 3T3-L1 and C2C12 cells were cultured with $25 \mathrm{mM}$ glucose (Growth Medium 2 - GM2). Crude extract OBE100, triterpenoid mixtures (M1-M5), UA, OA, and UAL were reconstituted in dimethyl sulfoxide (DMSO) at $25 \mathrm{mg} / \mathrm{ml}$ (stock solution). Final concentration of the compounds in culture medium is shown in Table I and Tables SI-SIII.

\section{Macrophage cell culture and activation}

J774A.1 cells were cultured in GM1. At 80\% confluence J774A.1 cells were incubated in GM1 containing $100 \mathrm{ng} / \mathrm{ml}$ lipopolysaccharide (LPS) and $20 \mathrm{ng} / \mathrm{ml}$ interferon gamma (IFN-y) (Activation medium - AM) for 24h. Treatments were added during the last 6h. MTT cell proliferation assay and Dihydrorhodamine (DHR) assay were performed, supernatants were collected to evaluate cytokine concentration, and RNA was collected to evaluate inflammation related gene transcription.

Table I. Combination of triterpenoids to evaluate (OBE100 $100 \mu \mathrm{g} / \mathrm{ml}$ ).

\begin{tabular}{|c|c|c|c|}
\hline \multirow{2}{*}{ Concentration of triterpenoid mixtures } & \multicolumn{3}{|c|}{ Triterpenoid concentration } \\
\hline & UA ( $\mu \mathrm{g} / \mathrm{ml})$ & OA ( $\mu g / m l)$ & UAL ( $\mu \mathrm{g} / \mathrm{ml})$ \\
\hline OBE100 $(100 \mu \mathrm{g} / \mathrm{ml})$ & 47.6 & 14.4 & 16 \\
\hline M1 $(78 \mu \mathrm{g} / \mathrm{ml})$ & 47.6 & 14.4 & 16 \\
\hline M2 (78 $\mu \mathrm{g} / \mathrm{ml})$ & 16 & 14.4 & 47.6 \\
\hline M3 $(78 \mu \mathrm{g} / \mathrm{ml})$ & 14.4 & 47.6 & 16 \\
\hline M4 $(78 \mu \mathrm{g} / \mathrm{ml})$ & 23.84 & 7.2 & 46.96 \\
\hline M5 $(78 \mu \mathrm{g} / \mathrm{ml})$ & 26 & 26 & 26 \\
\hline
\end{tabular}

UA: Ursolic acid; OA: Oleanolic acid; UAL: Ursolic acid lactone. 


\section{Adipocyte cell culture and differentiation}

3T3-L1 pre-adipocytes were cultured in GM2. Differentiation was induced 2 days postconfluence by adding GM2 containing $0.5 \mathrm{mM}$ 3-isobutyl-1-methylxanthine (IBMX), $0.25 \mu \mathrm{M}$ dexamethasone, $2 \mu \mathrm{M}$ Rosiglitazone and $1 \mu \mathrm{g} /$ $\mathrm{ml}$ insulin. After 2 days of incubation, medium was replaced with GM2 containing $1 \mu \mathrm{g} / \mathrm{ml}$ insulin. Two days later, medium was replaced by GM2 and incubated for another 7 days with the different treatments (Replacing it every 2 days). MTT cell proliferation assay was performed, supernatants were collected to evaluate adipokine concentration, and cells were stained to evaluate fatty acid concentration.

\section{Myotube cell culture and differentiation}

C2C12 cells were cultured in GM2 and were differentiated into myotubes using DMEM with 5.5 mM glucose, 2\% Horse Serum, 2 mM glutamine, and $1 \%$ penicillin/streptomycin (Growth medium 3 - GM3) for 4 days. The medium was replaced by GM3 and incubated for another 4 hours with the different treatments. MTT cell proliferation assay was performed and supernatants were collected to evaluate glucose concentration.

\section{Cell viability}

Adipocytes, myotubes and macrophages were treated at different concentrations of the triterpenoid mixtures according to the cell type $(3.13,6.25,12.5,25,50,100$ and $200 \mu \mathrm{g} / \mathrm{ml})$ and a MTT Cell Viability Assay Kit (Sigma-Aldrich, St. Louis, Mo, USA) was used. MTT was added to the cells for 2 hours. After that time, formazan crystals were dissolved by adding DMSO. Absorbance was measured at $570 \mathrm{~nm}$ in a Varioskan TM LUX microplate multilector (Thermo Fisher Scientific, Waltham, MA, USA). Results from this test established the concentrations of triterpenoid mixtures used to analyze their anti-adipogenic, anti-inflammatory and hypolipidemic capacity.

\section{Determination of oxidative stress in J774.A1 cells}

Dihydrorhodamine 123 (DHR) was applied as qualitative marker of intracellular reactive oxygen species (ROS). J774A.1 macrophage cells were activated and treated. Phorbol 12-myristate 13-acetate (PMA) was used as positive control. Cells were re-suspended in PBS with $0.001 \mathrm{mM}$ DHR, incubated for $15 \mathrm{~min}$ and analyzed using BD LSRFortessa ${ }^{\text {TM }}$ (BD) Cytometer (excitation 488 $\mathrm{nm}$, emission $530 \mathrm{~nm}$ ).

\section{RNA extraction and real-time PCR in J774.A1 cells}

Total RNA was extracted from cells with the RNeasy kit coupled with DNase treatment for genomic DNA removal (QIAGEN, Valencia, (A, USA), and reverse transcription reaction was performed with $500 \mathrm{ng}$ total RNA, $50 \mathrm{ng} /$ $\mu \mathrm{l}$ random hexamers, $10 \mathrm{mM}$ dNTP Mix, $20 \mathrm{mM}$ Tris- $\mathrm{HCl}$ pH 8.4, $50 \mathrm{nM} \mathrm{KCl,} 2.5 \mathrm{mM} \mathrm{MgCl2}, 40$ $\mathrm{U} / \mu \mathrm{l}$ RNaseOut, and $200 \mathrm{U} / \mu \mathrm{l}$ Superscript III RT (Invitrogen, Waltham, MA, USA), according to the manufacturers' instructions. Real-time quantitative PCR (qPCR) analyses were performed with 50 ng cDNA and 600 nM sense and antisense primers (Integrated DNA Technologies, Coralville, IA, USA) in a final reaction volume of $25 \mu \mathrm{l}$ using the Maxima SYBR Green/ROX qPCR Master Mix (Thermo-Fisher Scientific, Waltham, MA, USA) and the CFX96 real-time PCR detection system (Bio-Rad, Hercules, CA, USA). The program for thermal cycling was $10 \mathrm{~min}$ at $95^{\circ} \mathrm{C}$, followed by 40 cycles of $15 \mathrm{~s}$ at $95^{\circ} \mathrm{C}, 30 \mathrm{~s}$ at $60^{\circ} \mathrm{C}$, and $30 \mathrm{~s}$ at $72{ }^{\circ} \mathrm{C}$. Results were normalized to the cyclophilin expression level. The expression of the inflammatory marker genes TNF- $\alpha, I L-1 \beta$ and IL- 6 was evaluated and the relative amount of the whole mRNA was calculated using the comparative or $\Delta \Delta \mathrm{Ct}$ method. All the sequencespecific oligonucleotide primers (Table SIV) were obtained from Invitrogen. Serial cDNA dilution 
curves were produced in order to calculate the amplification efficiency of all genes. A graph of threshold cycle (Ct) vs. log10 relative copy number of the sample from a dilution series was produced. The slope of the curve was used to determine amplification efficiency using the formula: Efficiency $(\%)=\left(10^{\wedge}(-1 /\right.$ The Slope value)-1)*100.

\section{Quantification of cytokines in J774.A1 cells}

Cytokine production in J774A.1 cells was quantified using the mouse inflammation BDTM Cytometric Bead Array (CBA) kit (50TST, BD Biosciences, San Diego, CA, USA). Flow cytometry was performed using The BD LSR Fortessa ${ }^{\mathrm{TM}}$ cell analyzer. Results were normalized to the total protein concentration. Assays were performed according to the manufacturers instructions. The measured cytokines were: Interleukin-6 (IL-6), Interleukin-10 (IL-10), Monocyte Chemoattractant Protein -1 (MCP-1) and Tumor Necrosis Factor- $\alpha$ (TNF- $\alpha)$.

\section{Measurement of glucose concentration in C2C12 cells}

C2C12 myotubes were incubated for $4 \mathrm{~h}$ in GM1 with treatments. Then, $500 \mu \mathrm{l}$ of supernatant were collected, and glucose concentration was measured using the Glucose Oxidase Assay Kit (Invitrogen, Waltham, MA, USA). To calculate glucose utilization, the remaining glucose in the culture medium after incubation with controls, OBE100 and mixtures was subtracted from the initial amount of glucose (5.5 mM).

\section{Measurement of triacylglycerol concentration in 3 T3-L1 cells}

Differentiated and treated 3T3-L1 cells were washed with PBS and fixed in 10\% formaldehyde at room temperature for $1 \mathrm{~h}$. Cells were washed with $60 \%$ isopropanol and completely dried. The fixed cells were stained with Oil Red-O solution (Sigma-Aldrich, St. Louis, Mo, USA) at room temperature for $30 \mathrm{~min}$ and washed with water. Cells were photographed with a 10X and 40X magnification. The stain of lipid droplets was extracted with $100 \%$ isopropanol and the absorbance was measured at $492 \mathrm{~nm}$ in a Varioskan ${ }^{\text {TM }}$ LUX multimode microplate reader (Thermo- Fisher Scientific, Waltham, MA, USA). Preadipocytes and differentiated adipocytes were used as controls.

\section{Quantification of adipokines in 3T3-L1 cells}

Leptin (ab100718) and Adiponectin (ab108785) kits (Abcam, Cambridge, UK) were used for the quantitative measurement of mouse adipokines in culture medium after cells treatment. The absorbance of each sample was measured using a Varioskan ${ }^{\mathrm{TM}}$ LUX multimode microplate reader (Thermo-Fisher Scientific, Waltham, MA, USA). Results were normalized to the total protein concentration. Assays were performed according to the manufacturers instructions.

\section{Statistical analysis}

Data are presented as means \pm SEM. Comparisons between groups were analyzed using one-way analysis of variance (ANOVA) followed by a Dunnett post hoc test. Statistical significance was set at $p<0.05$. Analyses were performed with the Prism 4 (GraphPad software Inc) statistical software.

\section{RESULTS}

\section{Effect of triterpenoid mixtures on J774A.1 macrophage cell line}

Macrophage cell viability was similarly affected by OBE100, M2, and M4; these treatments all have a high concentration of UAL and produced less than a $20 \%$ reduction in viability of 3774 A.1 cells. This effect was not observed when cells were treated with M1, M3 or M5, which all produced larger 
a)
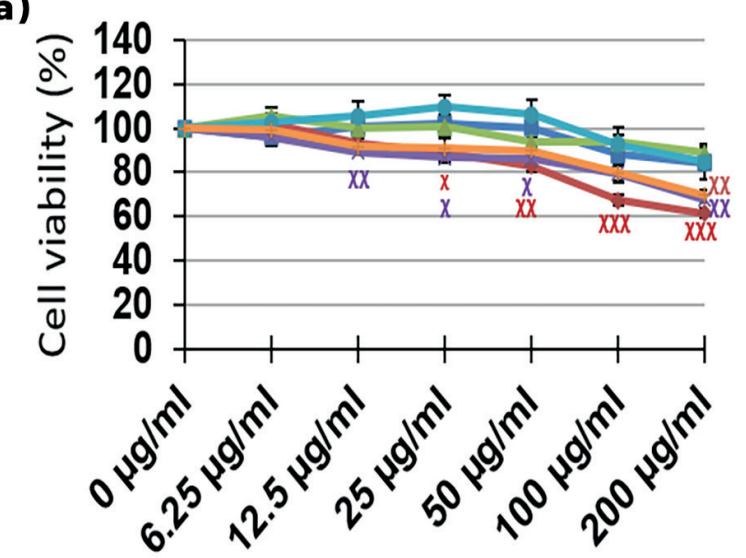

$=\mathrm{OBE} 100 \multimap \mathrm{M} 1 \multimap \mathrm{M} 2 \leftarrow \mathrm{M} 3 \rightarrow \mathrm{M} 4 \leftarrow \mathrm{M} 5$

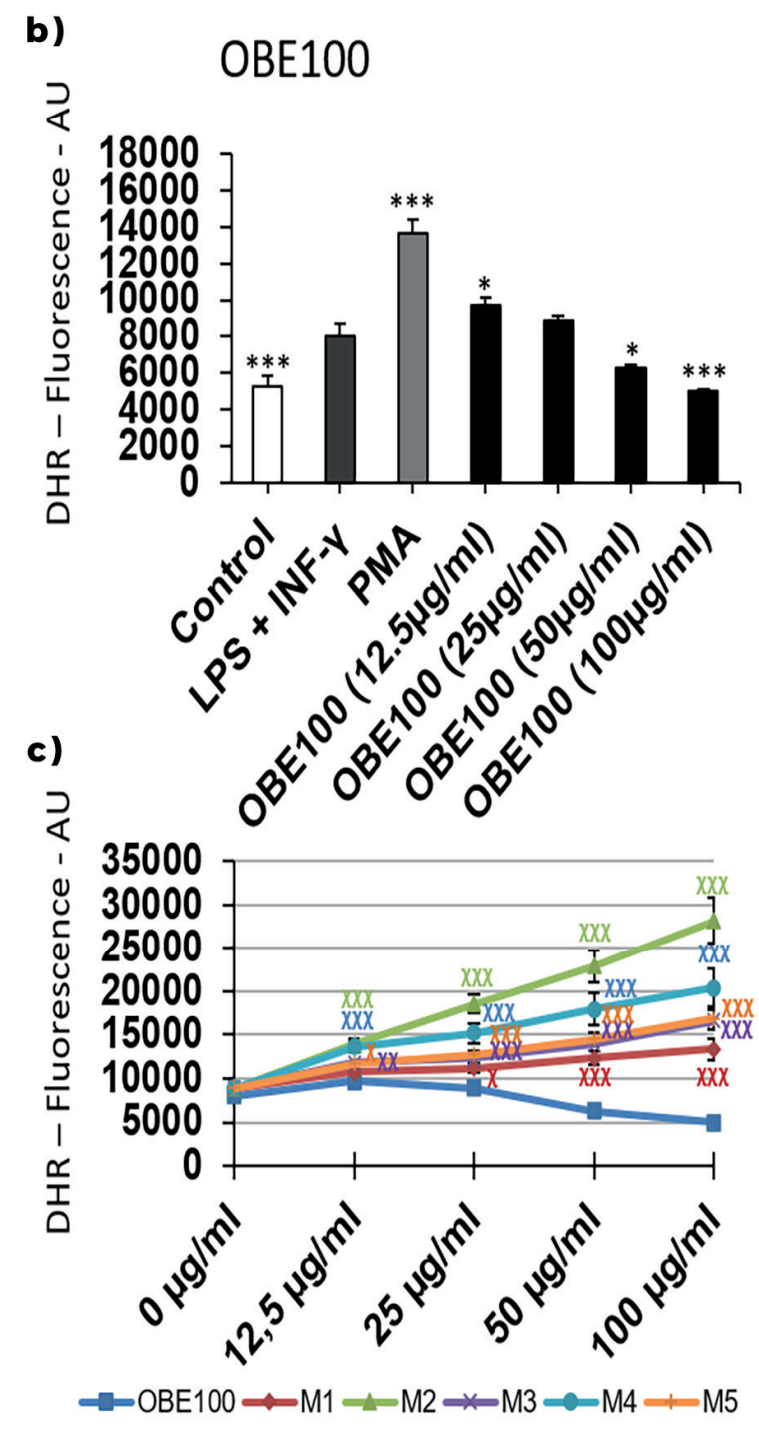

Figure 1. Effect of triterpenoid mixtures on cell viability and oxidative burst in activated J774A.1 macrophages. a) Activated J774A.1 cells were treated with various doses $(0-200 \mu \mathrm{g} / \mathrm{ml})$ of OBE100, M1, M2, M3, M4 and M5. Cell viability was measured by the MTT assay after 6 hours of treatment. The percentage of viable cells was calculated by defining the cell viability without treatment as $100 \%$. Values are expressed as mean \pm SEM of three independent experiments. (b) and (c) Activated J774A.1 cells were treated with various doses $(0-100 \mu \mathrm{g} / \mathrm{ml})$ of OBE100, M1, M2, M3, M4 and M5 for 6 hours. Dihydrorhodamine 123 (DHR) was applied as qualitative marker of intracellular reactive oxygen species (ROS). PMA was used as positive control. Values are expressed as mean \pm SEM of three independent experiments. ${ }^{*}<0.05$ vs LPS+INF- $\gamma$ (activated cells), ***< 0.001 vs LPS+INF- $\gamma$ (activated cells), $x \quad 0.05$ vs $0 B E 100, x x<0.01$ vs OBE100, $x x x<0.001$ vs OBE100, (ANOVA with Dunnett's post hoc test).

dose-dependent cytotoxic effects compared with OBE100 (Figure 1a). Treating activated macrophages with OBE100 or triterpenoid mixtures yielded different results in reactive oxygen species (ROS) production. ROS generation was reduced by treatment with the natural extract in a dosedependent manner (Figures 1b-c). However, treatment with M1, M2, M3, M4, or M5 caused a dose-dependent increase in ROS production (Figure 1c). We analyzed the anti-inflammatory effects of triterpenoid mixtures at triterpenoid concentrations of 39 and $78 \mu \mathrm{g} / \mathrm{ml}$. All treatments significantly decreased IL-1 $1 \beta$ gene expression, in activated J774A.1 cells, however, only OBE100 and M1 consistently reduced TNF- $\alpha$ and IL- 6 gene expression at both concentrations (Figures 2a-c). Treatment with OBE100, M1, or M2 significantly reduced IL-6 protein expression and only OBE100 led to a significant reduction in the expression of TNF- $\alpha$ and MCP1 pro-inflammatory proteins at both concentrations (Figures 3a-c). OBE100 and M1 significantly increased anti-inflammatory IL10 protein expression compared with untreated activated macrophages (Figure $3 \mathrm{~d}$ ). 
a)
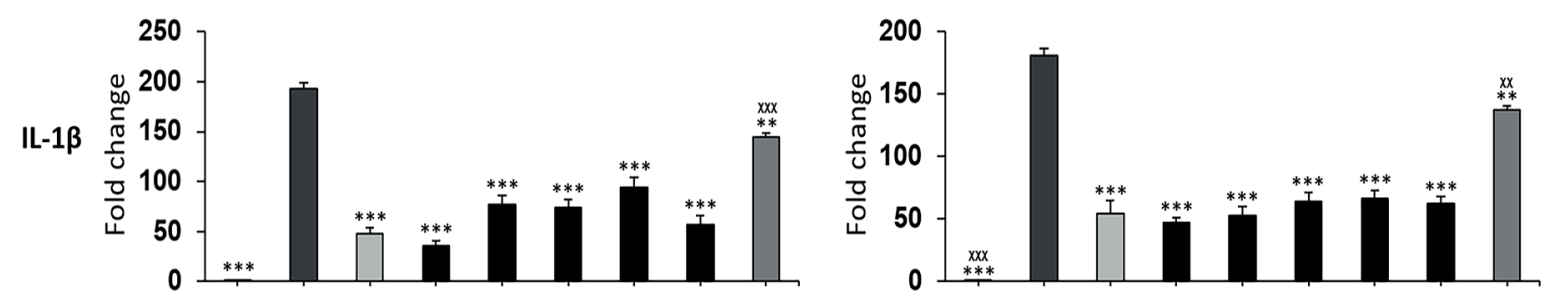

b)
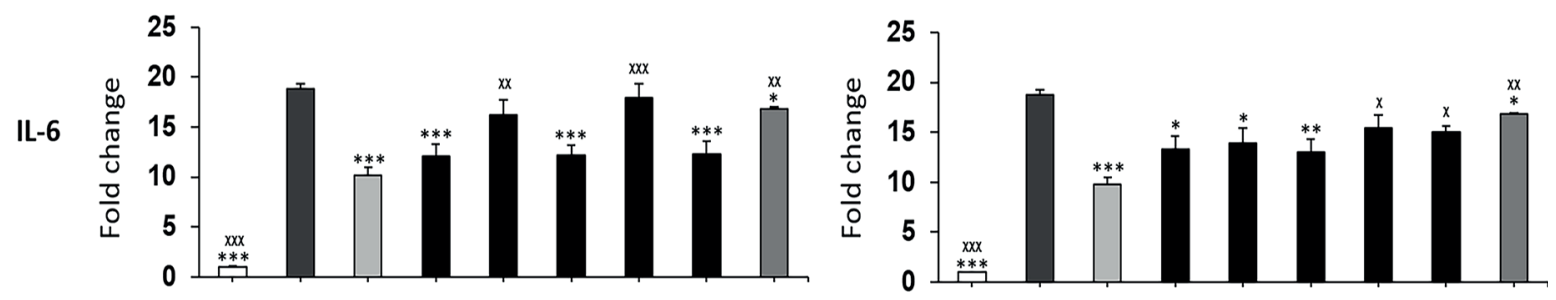

c)
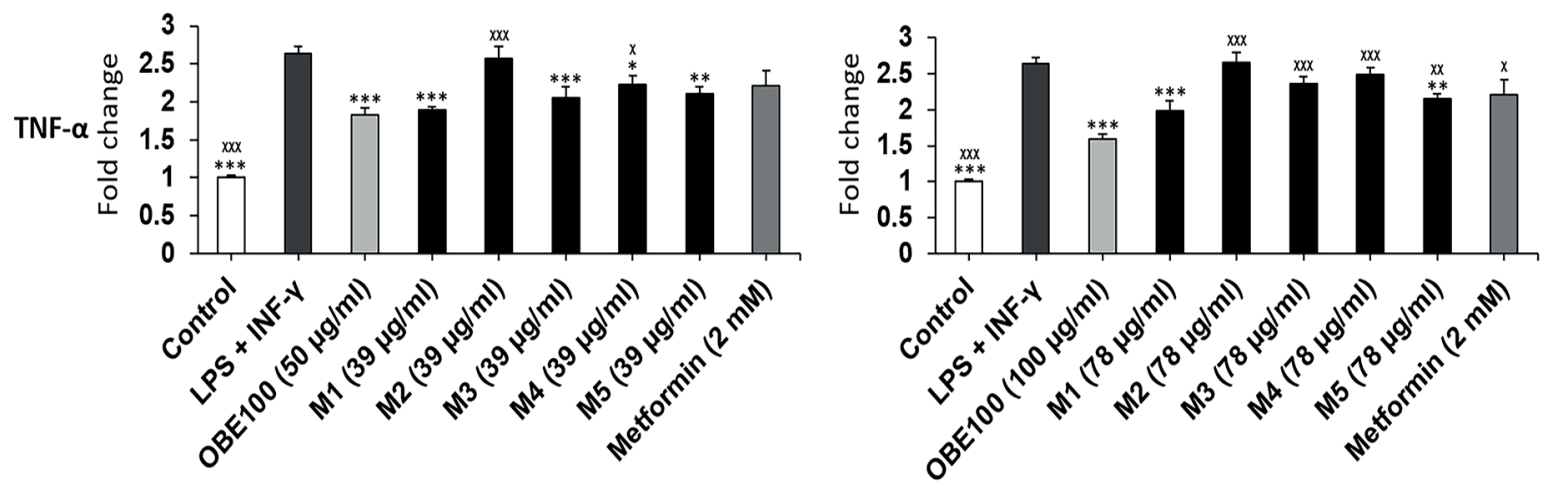

Figure 2. Effect of triterpenoid mixtures on the expression of pro-inflammatory genes in activated J774A.1 macrophages. Relative expression of (a) IL-1 $\beta$, (b) IL- 6 and (c) TNF- $\alpha$ mRNA transcripts is shown. Values are expressed as mean \pm SEM of three independent experiments, normalized to the cyclophilin $\beta$ gene expression. Metformin was used as positive control. ${ }^{*}<0.05$ vs LPS+INF- $\gamma$ (activated cells), $* *<0.01$ vs LPS+INF- $\gamma$ (activated cells), $* * *<0.001$ vs LPS+INF- $y$ (activated cells), $x<0.05$ vs OBE100, $x x<0.01$ vs OBE100, $x x x<0.001$ vs OBE100 (ANOVA with Dunnett's post hoc test).

\section{Effect of triterpenoid mixtures on $\mathrm{C} 2 \mathrm{C} 12$ myocyte cell line}

Differentiated myotube viability in the $\mathrm{C} 2 \mathrm{C} 12$ cell line was similarly affected by OBE100, M2, M3, M4, or M5 treatments. All treatments with concentrations up to $100 \mu \mathrm{g} / \mathrm{mL}$ resulted in less than $20 \%$ cell cytotoxicity, which increased to more than $20 \%$ at $200 \mu \mathrm{g} / \mathrm{ml}$. M1 significantly reduced cell viability compared with OBE100 at the highest concentration (Figure 4a). To compare the effect of treatments on glucose uptake capacity, C2C12 myotubes were treated with OBE100 and triterpenoid mixtures, at triterpenoid concentrations of 39 and $78 \mu \mathrm{g} / \mathrm{ml}$ (Figure 4b). OBE100 and M1 significantly reduced glucose levels in culture supernatants, at both concentrations however, treatment with OBE100 induced the greatest glucose reduction (43.6\% and $25.2 \%$, respectively). Compared with other treatments, including when insulin was used as a positive control, treating myocytes with OBE100 at lowest concentration significantly increased cell glucose uptake. Furthermore, compared with the control group, treatment with $\mathrm{M} 2, \mathrm{M} 4$, or M5, at 39 and $78 \mu \mathrm{g} / \mathrm{ml}$, and $\mathrm{M} 3$, at $78 \mu \mathrm{g} / \mathrm{ml}$, did not significantly reduce supernatant glucose levels. 

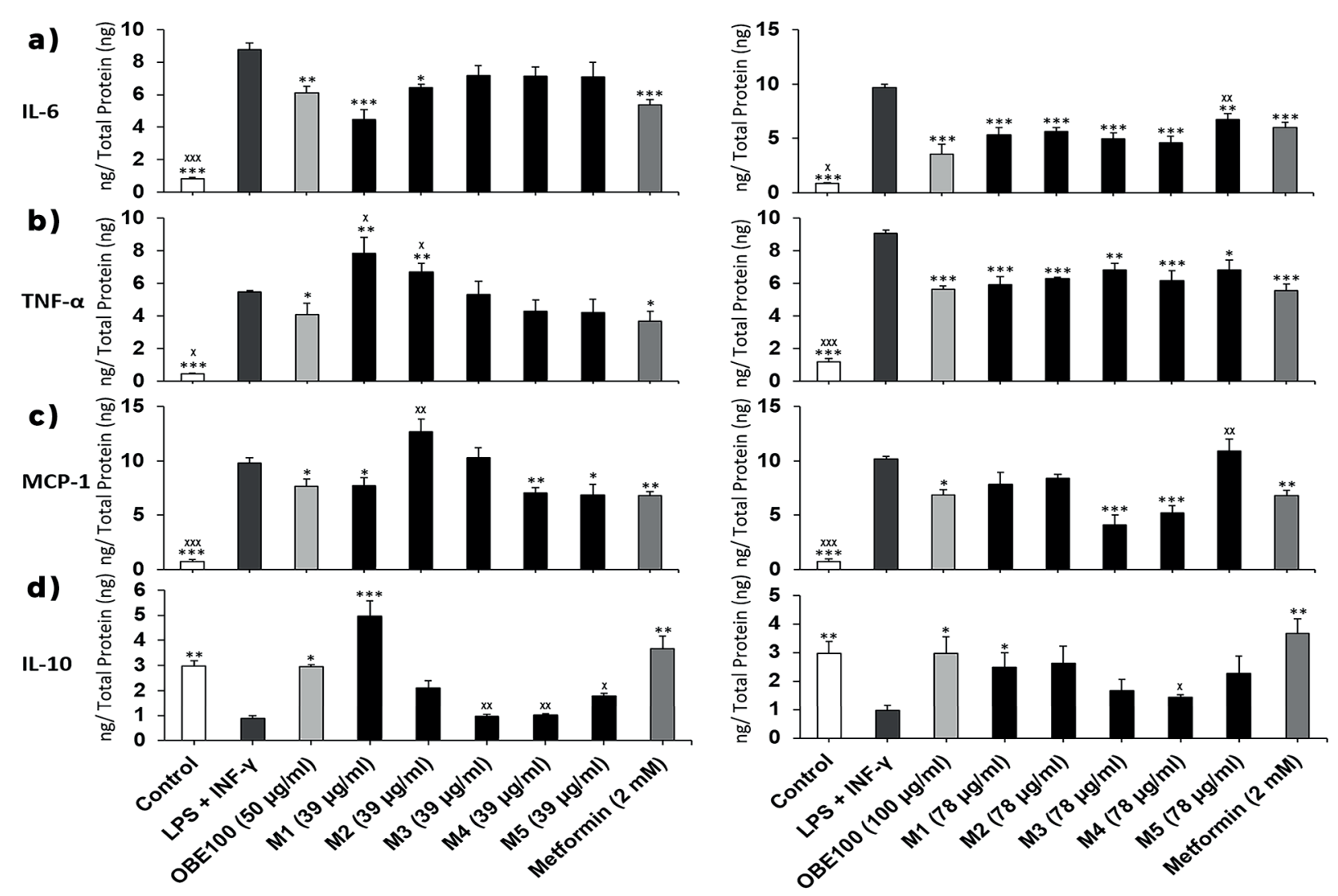

Figure 3. Effect of triterpenoid mixtures on activated J774A.1 macrophage protein expression. (a) IL-6, (b) TNF- $\alpha$, (c) MCP-1 and (d) IL-10 concentration in culture supernatant is shown. Values are expressed as mean \pm SEM of three independent experiments. Metformin was used as positive control. ${ }^{*}<0.05$ vs LPS+INF- $\gamma$ (activated cells), ** $<0.01$ vs LPS+INF-y (activated cells), *** $<0.001$ vs LPS+INF- $y$ (activated cells), $x<0.05$ vs OBE100, $x x<0.01$ vs 0 BEE100, $x x x$ $<0.001$ vs OBE100 (ANOVA with Dunnett's post hoc test).

Effect of triterpenoid mixtures on 3T3-L1 adipocyte cell line

Viability in the 3T3-L1 adipocyte cell line was similarly affected by OBE100 or M2 treatment, where $50 \mu \mathrm{g} / \mathrm{ml}$ of either treatment resulted in less than $20 \%$ cell cytotoxicity. However, treatment with $25 \mu \mathrm{g} / \mathrm{ml} \mathrm{M1,} \mathrm{M3,} \mathrm{M4,} \mathrm{or} \mathrm{M5}$ resulted in more than $20 \%$ cytotoxicity. All these mixtures significantly reduced 3T3-L1 cell viability compared with OBE100, especially at the highest concentrations (Figure 5a). The effect of the treatments on 3T3-L1 adipocyte lipid accumulation is shown in Figure $5 b$ and Figure S1 - Supplementary Material. Cells treated with OBE100 at 12.5 and $25 \mu \mathrm{g} / \mathrm{ml}(9.8$ and $19.5 \mu \mathrm{g} / \mathrm{ml}$ triterpenoid concentration) had significantly reduced lipid content (16\% and $32 \%$, respectively). The M1 mixture at 9.8 and $19.5 \mu \mathrm{g} / \mathrm{ml}$ decreased lipid accumulation (18\% and $43 \%$, respectively), while treatment with $\mathrm{M} 2$ at $9.8 \mu \mathrm{g} / \mathrm{ml}$ and $19.5 \mu \mathrm{g} / \mathrm{ml}$ reduced fat load (12\% and $24 \%$, respectively). M3, M4, and M5 treatments decreased lipid content at $9.8 \mu \mathrm{g} /$ $\mathrm{ml}$, but M4 and M5 lost this effect when the concentration treatment was increased at 19.5 $\mu \mathrm{g} / \mathrm{ml}$. M3 treatment induced a high death rate and it was not used at the highest concentration. We assessed how treatment with these compounds, at 9.8 and $19.5 \mu \mathrm{g} / \mathrm{ml}$ triterpenoid concentrations, affected leptin and adiponectin 
a)

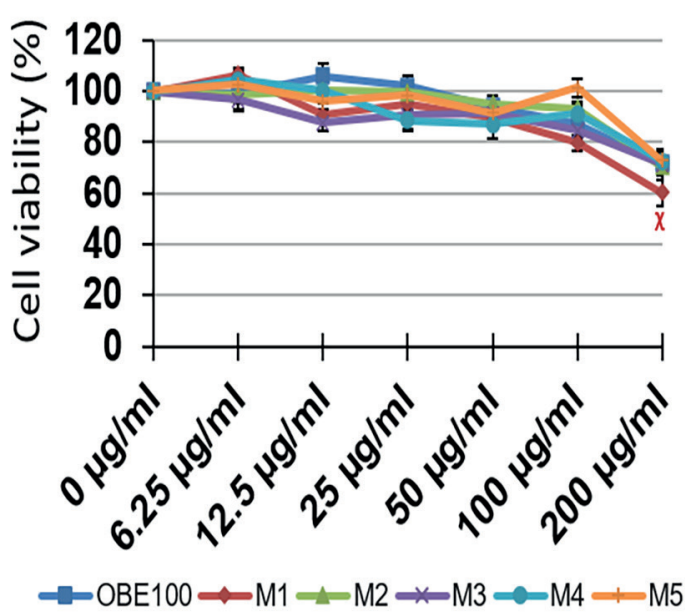

b)
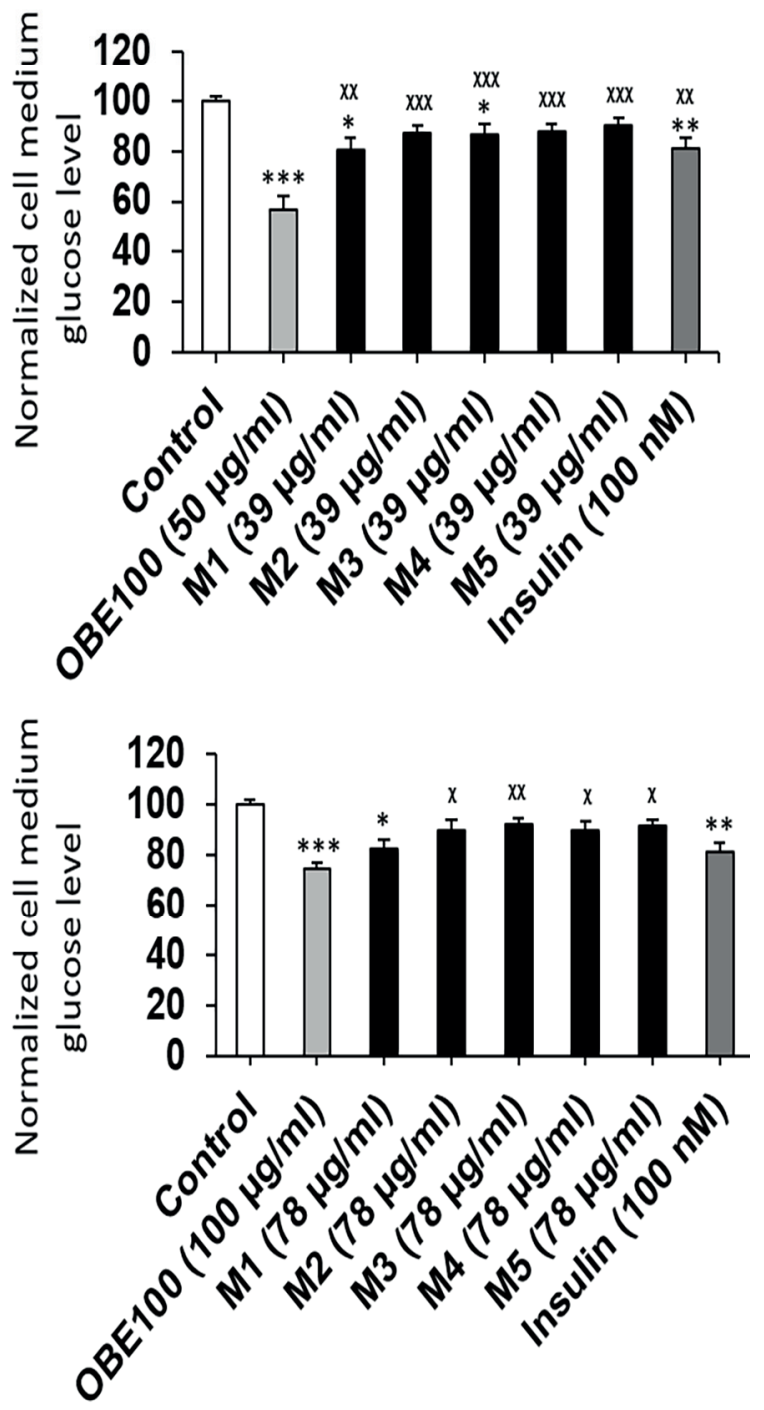

Figure 4. Effect of triterpenoid mixtures on cell viability and glucose uptake in $\mathrm{C} 2 \mathrm{C} 12$ cells.

(a) Differentiated C2C12 cells were treated with various doses (0-200 $\mathrm{\mu g} /$ $\mathrm{ml}$ ) of OBE100, M1, M2, M3, M4 and M5. Cell viability was measured by the MTT assay after 4 hours of treatment. The percentage of viable cells was calculated by defining the cell viability without treatment as $100 \%$. Values are expressed as mean \pm SEM of three independent experiments. (b) Cells were treated with OBE100, M1, M2, M3, M4, and M5 and glucose was measured in cultured supernatant after $4 \mathrm{~h}$ of treatment by the glucose oxidase technique. Insulin was used as positive control. Values are expressed as mean \pm SEM of three independent experiments. * $<0.05$ vs Control, ** < 0.01 vs Control, *** $<0.001$ vs Control, $x$ $<0.05$ vs OBE100, $x x<0.01$ vs OBE100, $x x x<0.001$ vs OBE100 (ANOVA with Dunnett's post hoc test).

protein expression in 3T3-L1 adipocytes (Figures 6a-b). All triterpenoid mixtures, except M2 at 9.8 $\mu \mathrm{g} / \mathrm{ml}$, significantly reduced leptin expression compared with differentiated adipocytes. All treatments reduced adiponectin expression at the highest concentration, although M3, M4, or M5 had no effect on adiponectin levels at the lowest dose.

\section{DISCUSSION}

Extracts from Eu have hypoglycemic, antiinflammatory, and antiadipogenic effects (Ceballos et al. 2018, Guillén et al. 2015). We have previously determined that UA, OA, and UAL are the major compounds identified in the OBE100 raw fraction. OBE100 $(100 \mu \mathrm{g} / \mathrm{ml})$ contains: 47.65 $\mu \mathrm{g} / \mathrm{ml}(104.3 \mu \mathrm{M})$ UA, $14.05 \mu \mathrm{g} / \mathrm{ml}(30.8 \mu \mathrm{M})$ $\mathrm{OA}$, and $16.3 \mu \mathrm{g} / \mathrm{ml}(35.8 \mu \mathrm{M})$ UAL (Ceballos et al. 2018). In this study, macrophage, myocyte, and adipocyte cellular models were used to 
a)

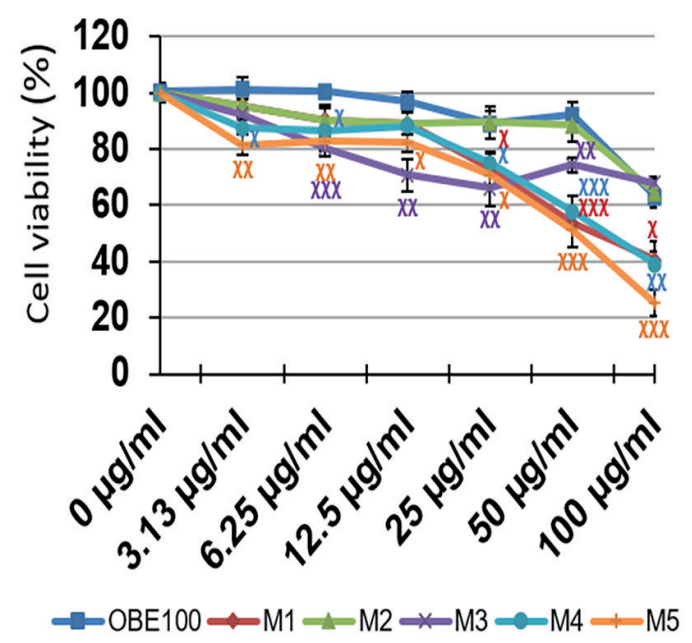

b)

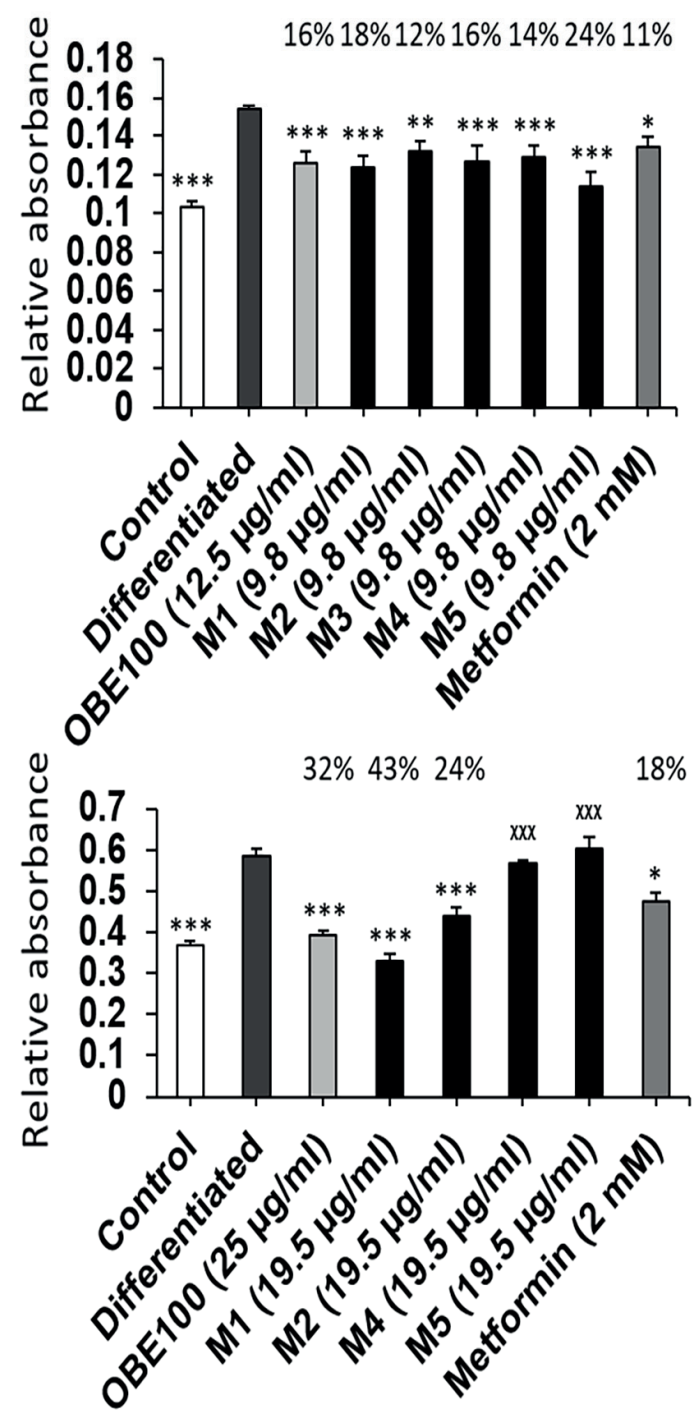

Figure 5. Effect of triterpenoid mixtures on cell viability and lipid accumulation in 3T3-L1 adipocytes. (a) Differentiated 3T3-L1 cells were treated with various doses $(0-100 \mu \mathrm{g} / \mathrm{ml})$ of OBE100, M1, M2, M3, M4 and M5. Cell viability was measured by the MTT assay after 7 days of treatment. The percentage of viable cells was calculated by defining the cell viability without treatment as $100 \%$. Values are expressed as mean \pm SEM of three independent experiments. $x<$ 0.05 vs $0 B E 100, x x<0.01$ vs $0 B E 100, x x x<0.001$ vs OBE100 (b) Lipid accumulation was quantified after 7 days of treatment. Metformin was used as positive control. Values are expressed as mean \pm SEM of three independent experiments. ${ }^{*}<0.05$ vs Differentiated, $* *<0.01$ vs Differentiated, $* * *<0.001$ vs Differentiated, $x x x<0.001$ vs OBE100 (ANOVA with Dunnett's post hoc test).

compare OBE100 effects to those produced by reconstituted mixtures of $U A, O A$, and $U A L$ with the same concentration and proportion of triterpenoids found in OBE100 (M1) or different proportions (M2, M3, M4, and M5) (Table I, Tables SI-SIII).

Cell viability assays showed that OBE100 and M2 had the lowest toxicity in all the cell lines, while the rest of the treatments resulted in a higher rate of cell death, depending on the cell line. Interestingly, treatment with M1 significantly increased cell toxicity compared with OBE100 in all cell lines. OBE100 and M1 contain the same amount and proportion of the different triterpenoids, indicating that unidentified molecules present in the natural extract contribute to cellular protection from toxicity. Triterpenoids have anti-inflammatory activities, but they also present cytotoxic properties (Chudzik et al. 2015). Our results confirmed that these molecules, regardless of their combination, inhibit the production of inflammatory cytokines (Figures $2 \mathrm{a}-\mathrm{c}$ and $3 \mathrm{a}-\mathrm{c}$ ); however, cell viability is less affected by OBE100, indicating that the minor compounds present in the natural extract possibly reduce the toxicity of the triterpenoid mixture. Data on UAL toxicity 

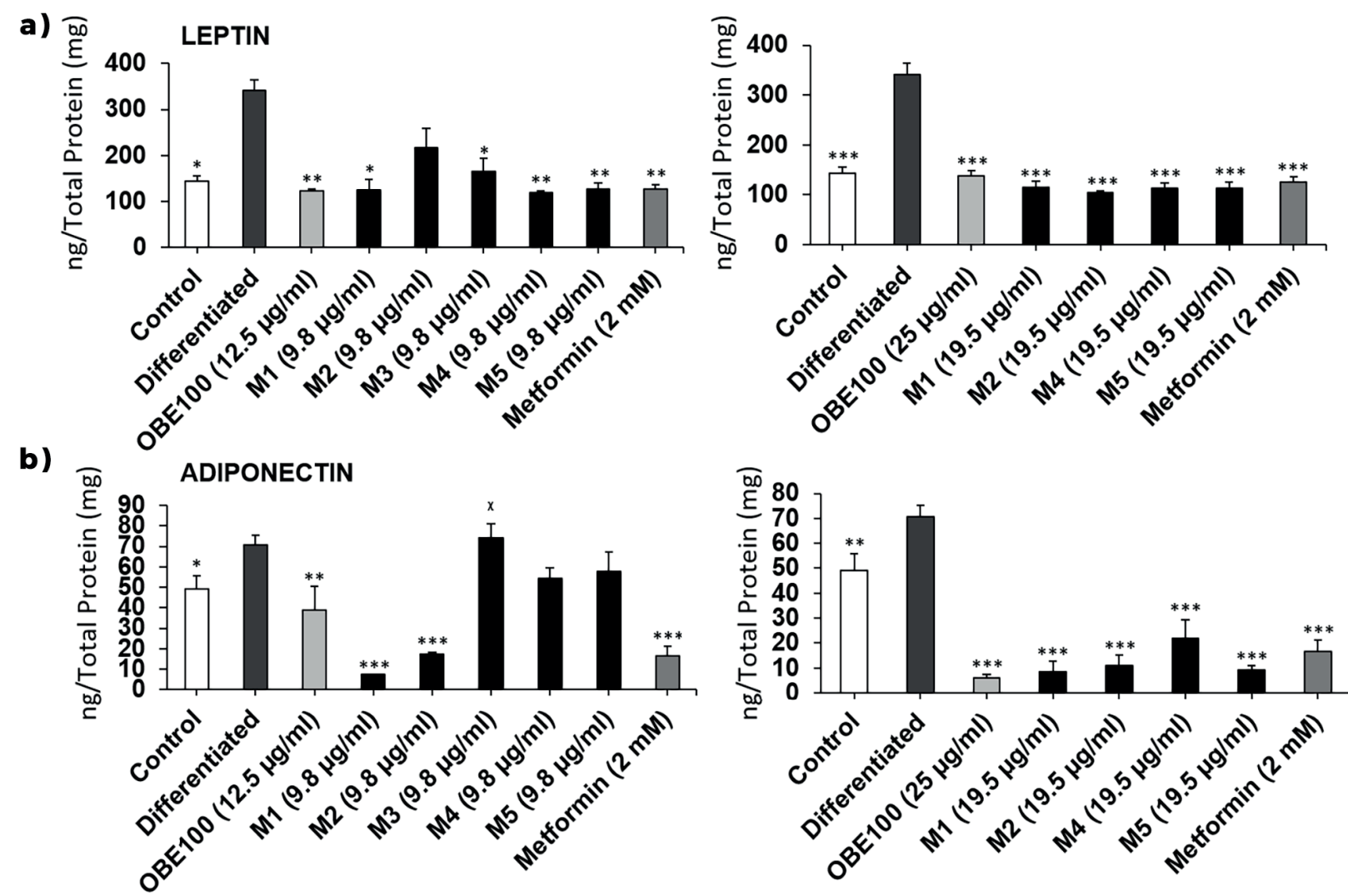

Figure 6. Effect of triterpenoid mixtures on protein expression in 3T3-L1 adipocytes.

Differentiated 3T3-L1 cells were treated with OBE100, M1, M2, M3, M4 and M5. (a) Amount of leptin and (b) Amount of adiponectin present in the supernatant of the cells after 7 days of treatment. Values are expressed as mean \pm SEM of three independent experiments. ${ }^{*}<0.05$ vs Differentiated, ${ }^{* *}<0.01$ vs Differentiated, ${ }^{* *}<0.001$ vs Differentiated, $x<0.05$ vs OBE100 (ANOVA with Dunnett's post hoc test).

is lacking, although cytotoxic activities of UA and OA have been described in different cell lines (Akihisa et al. 2006, Chudzik et al. 2015). In our study, mixtures richer in UA and OA reduced cell viability, especially in the longest treatments. However, treatment with M2, which contains the highest amount of UAL, showed similar toxicity to OBE100 in each cell culture. This result suggests that UAL may be less cytotoxic than UA and OA.

The correlation between obesity, adipose tissue inflammation, and metabolic disease make inflammatory pathways an attractive target for treating metabolic diseases such as T2DM. However, clinical trial results of antiinflammatory agents have been disappointing (Li et al. 2014, Reilly et al.2017). A promising strategy to prevent inflammatory responses in obese adipose tissues is using novel compounds derived from medicinal plants that modulate transcription factors which control inflammation, primarily through NF-KB and JNK (Saad et al. 2017). Obesity is a state of chronic oxidative stress and inflammation; although it is not fully understood if the alteration of redox balance is a trigger or a result of obesity, oxidative stress promotes pro-inflammatory signalling (Asghar et al. 2017, Thomas et al. 2017). In our study only OBE100 treatment reduced ROS production while the formulated triterpenoid mixtures caused a dose-dependent increase in ROS levels and these results are consistent with other studies where even lower doses of UA or OA (up to $10 \mu \mathrm{g} / \mathrm{mL}$ ) enhanced ROS production in macrophages (López-García et al. 2015, Podder 
et al. 2015). In our study, all the formulated mixtures, independent of how triterpenoids were mixed, significantly increased ROS levels compared with OBE100 (Figure 1c). This data support the idea that minor compounds present in OBE100 have beneficial functions reducing oxidative stress and cytotoxicity.

We confirmed that different triterpenoid mixtures have anti-inflammatory effects at triterpenoid concentrations of 39 and $78 \mu \mathrm{g} / \mathrm{ml}$; however, treatment effectiveness depended on the mixture. These differences were observed when we analyzed both inflammatory gene and protein expression. OBE100 and M1 showed a more consistent anti-inflammatory effect compared with the other triterpenoid mixtures and both were similar to the positive control (metformin) effect (Figure 3a-d). Numerous studies have demonstrated the anti-inflammatory activities of $\mathrm{OA}$ and $\mathrm{UA}$. These molecules regulate multiple proteins such as ERK, JNK, NF-KB, NF-AT, and $A P-1$, inducing a reduction in the expression of pro-inflammatory cytokines and promoting the expression of anti-inflammatory cytokines, among them IL-10 (Cargnin et al. 2017, Liu 2005, Pollier et al. 2012, Seo et al. 2018, Tao et al. 2018). In our study, all triterpenoid combinations had an anti-inflammatory effect, and these results are consistent with the properties previously described for these molecules. The antiinflammatory potency present in both OBE100 and M1 may be explained by both treatments containing the highest amount of UA tested. Interestingly, OBE100 was the only treatment that reduced the expression of all the proinflammatory cytokines analyzed and increased the expression of IL-10 at all concentrations. This particularly potent effect may be a consequence of synergism with the undescribed minority fraction present in the natural extract. We also reported that ROS were only reduced with OBE100 treatment, and ROS reduction may contribute an improved anti-inflammatory action in comparison with the direct effect triterpenoids alone have because ROS are important mediators in activating pro-inflammatory signalling pathways in macrophages (Naha et al. 2010, Rendra et al. 2019).

Skeletal muscle is the most important organ for whole-body glucose homeostasis. This tissue is responsible for approximately $80 \%$ of insulin-stimulated whole-body glucose uptake and disposal under normal conditions (Wu \& Ballantyne 2017). Treatments that increase insulin sensitivity in skeletal muscle cells would have tremendous potential to improve blood glucose homeostasis. Treatment with pentacyclic triterpenes promotes glucose uptake in myotubes. These molecules stimulate GLUT4 translocation and enhance basal and insulin-stimulated glucose uptake (Sharma et al. 2018). Both UA and OA have been shown to exhibit this property through Akt activation in C2C12 myotubes, and this effect is linked to the activation of the AMP activated protein kinase (AMPK) pathway (Munhoz et al. 2017). In our study, glucose uptake in C2C12 myotubes was induced markedly by OBE100 and M1, while the other evaluated mixtures showed little to no effect. The triterpenoid composition present in both mixtures appears to be the most effective in increasing glucose uptake in C2C12 cells, which is similar to the results observed in macrophages. Although OBE100 and M1 have the same amount and proportion of the different triterpenoids, the OBE100 effect is higher, increasing up to $43.6 \%$ glucose uptake. Thus, using a complete extract may produce a synergism between other active components present in the minority fraction that also improves its hypoglycemic effect in myocytes.

Previous studies have shown that treatment with UA or OA reduced lipid accumulation in 3T3-L1 cells. The effect of UA can be partially explained by the activation of AMPK (He et al. 2013, Quian. et al. 2015). In our study, OBE100, M1, and $\mathrm{M} 2$ reduced lipid content regardless of the concentration used. OBE100 results are consistent with those previously described (Ceballos et al. 2018), and no formulated compound significantly 
improved the reduction of cell triacylglycerol accumulation. It is interesting that the mixtures with highest amount of UA (OBE100 and M1) were more efficacious in reducing fat accumulation, indicating the importance of this molecule to produce this reduction.

Adiponectin has anti-inflammatory properties and improves insulin sensitivity in adipose tissue (Daniele et al. 2014). However, overexpression of adiponectin in 3T3-L1 fibroblasts stimulates C/EBP $\alpha$, PPAR-y and SREBP-1C gene expression and promotes their differentiation to adipocytes and the accumulation of greater amounts of larger lipid drops (Fu et al. 2005). A large amount of leptin is secreted by adipocytes in obesity conditions, and this explains the altered control of metabolic functions often associated with insulin resistance and the greater number of Th1 cells, CD8+ T cells, macrophages, and mast cells that have increased secretion of pro-inflammatory cytokines (Procaccini et al. 2012). In this regard, reducing the expression of both adipokines has beneficial effects in cell culture. OBE100 significantly reduced leptin and adiponectin levels, and this reduction was similar to the effect produced by treatment with metformin, used as a positive control. None of the triterpenoid mixtures significantly improved these results. M1 was the mixture with the most similar effects compared with the natural extract, indicating that UA may be the principal molecule responsible for these effects.

These findings provide evidence that combinations of UA, OA, and UAL can modulate glucose uptake and have anti-inflammatory and antilipogenic activities. Reconstituted triterpenoid mixtures did not enhance the effects produced by the combination of triterpenoids found in the natural extract. Secondary metabolites contained in the minor fraction of $22 \%$ of the extract may enhance the benefits of triterpenoids, as these metabolites are absent in the formulated mixtures. Using the complete extract may allow synergism between different active components that could act on different cell types and metabolic pathways. Such synergism has been described in several medicinal tests, including those for anti-inflammatory activity (Azab et al. 2016, Nemudzivhadi et al. 2014). There is significant potential to this therapeutic approach as most complex diseases, such as T2DM, are pathologically related to the interaction of multiple pathways, multiple genes, and multiple functional proteins (Yuan et al. 2017).

In conclusion, an extract of Eu (OBE100), with $U A, O A$, and UAL as the main molecules mixed with unknown minor metabolites, provided superior anti-inflammatory, hypoglycemic and hypolipidemic effects than any of the reconstituted triterpenoid mixtures. Furthermore, OBE100 has the advantages of lower toxicity and reduction of ROS production. Of all compounds tested, treatment with OBE100 would be the best potential phytopharmaceutical for treating T2DM, that could break the vicious cycle of immunometabolic dysregulation of this disease. Further research is necessary to study the complexity of the OBE100 extract, including the unknown triterpenoid UAL, to better understand the interaction of molecules that explains the beneficial effects.

\section{Acknowledgments}

This work was supported by COLCIENCIAS (Colombia) Grant no. 111577756880 and Universidad de Antioquia, GENMOL, Grant no. 2017-16968.

\section{REFERENCES}

AKIHISA T, KAMO S, UCHIYAMA T, AKAZAWA H, BANGO N, TAGUCHI Y \& YASUKA K. 2006. Cytotoxic Activity of Perilla Frutescens Var. Japonica Leaf Extract Is Due to High Concentrations of Oleanolic and Ursolic Acids. J Nat Med 60: 331-333.

AMBREEN A \& SHEIKH N. 2017. Role of Immune Cells in Obesity Induced Low Grade Inflammation and Insulin Resistance. Cell Immunol 15: 18-26.

AYELESO TB, MATUMBA MG \& MUKWEVHO E. 2017. Oleanolic Acid and Its Derivatives: Biological Activities and Therapeutic Potential in Chronic Diseases. Molecules 22(11): 1915. 
AZAB A, NASSAR A \& AZAB AN. 2016. Anti-Inflammatory Activity of Natural Products. Molecules 21(10): 13211-13219.

CARGNIN ST \& GNOATTO SB. 2017. Ursolic Acid from Apple Pomace and Traditional Plants: A Valuable Triterpenoid with Functional Properties. Food Chem 220: 477-489.

CEBALLOS S, GUILLÉN A, MUÑOZ DL, CASTAÑO A, ECHEVERRI LF, ACÍN S \& BALCÁZAR N. 2018. Immunometabolic Regulation by Triterpenes of Eucalyptus Tereticornis in Adipose Tissue Cell Line Models. Phytomedicine 50(3): 109-117.

CHUDZIK M, ILONA KORZONEK-SZLACHETA I \& WOJCIECH KRÓL W. 2015. Triterpenes as Potentially Cytotoxic Compounds. Molecules 20(1): 1610-1625.

DANIELE G ET AL. 2014. The Inflammatory Status Score Including IL-6, TNF- a, Osteopontin, Fractalkine, MCP-1 and Adiponectin Underlies Whole-Body Insulin Resistance and Hyperglycemia in Type 2 Diabetes Mellitus. Acta Diabetol 123-131.

DONATH MY \& SHOELSON SE. 2011. Type 2 Diabetes as an Inflammatory Disease. Nat Rev Immunol 11(2): 98-107.

GUILLÉN A, GRANADOS S, RIVAS KE, ESTRADA O, ECHEVERRI LF \& BALCÁZAR N. 2015. Antihyperglycemic Activity of Eucalyptus Tereticornis in Insulin-Resistant Cells and a Nutritional Model of Diabetic Mice. Adv Pharmacol Sci 2015: 418673.

HE K, SONG S, ZOU Z, FENG M, WANG D, WANG Y, LI X \& YE X. 2016. The Hypoglycemic and Synergistic Effect of Loganin, Morroniside, and Ursolic Acid Isolated from the Fruits of Cornus Officinalis. Phytother Res 30(2): 283-291.

HE Y, LI Y, ZHAO T, WANG Y \& SUN C. 2013. Ursolic Acid Inhibits Adipogenesis in 3T3-L1 Adipocytes through LKB1/AMPK Pathway. PLoS ONE 8(7): e70135.

KATASHIMA CK, SILVA VR, GOMES TL, PICHARD C \& PIMENTEL GD. 2017. Ursolic Acid and Mechanisms of Actions on Adipose and Muscle Tissue: A Systematic Review. Obes Rev 18(6): 700-711.

KRENTZ AJ, FUJIOKA K \& HOMPESCH M. 2016. Evolution of Pharmacological Obesity Treatments: Focus on Adverse Side-Effect Profiles." Diabetes Obes Metab 18(6): 558-570.

KZHYSHKOWSKA J. 2019. Reactive Oxygen Species (ROS) in Macrophage Activation and Function in Diabetes. Immunobiology 224(2): 242-253

LIU JJIE. 2005. Oleanolic Acid and Ursolic Acid: Research Perspectives. J Ethnopharmacol 100(1-2): 92-94.

LÓPEZ-GARCÍA S, CASTAÑEDA-SANCHEZ JI, JIMÉNEZ-ARELLANES A, DOMÍNGUEZ-LÓPEZ L, CASTRO-MUSSOT ME, HERNÁNDEZSANCHÉZ J \& JULIETA LUNA-HERRERA. 2015. Macrophage Activation by Ursolic and Oleanolic Acids during Mycobacterial Infection. Molecules 20(8): 14348-14364.

MAURYA A \& SRIVASTAVA SK. 2012. Determination of Ursolic Acid and Ursolic Acid Lactone in the Leaves of Eucalyptus Tereticornis by Hplc. J Braz Chem Soc 23(3): 468-472.
MLINDELI G, MABUZA L, NGUBANE P \& KHATHI A. 2018. The Effects of Plant-Derived Oleanolic Acid on Selected Parameters of Glucose Homeostasis in a Diet-Induced Pre-Diabetic Rat Model. Molecules 23(4): 794.

MOURYA A, AKHTAR A, AHUJA S, SAH SP \& KUMAR A. 2018. Synergistic Action of Ursolic Acid and Metformin in Experimental Model of Insulin Resistance and Related Behavioral Alterations." Eur J Pharmacol 15(835): 31-40.

MUNHOZ AC \& FRODE TS. 2017. Isolated Compounds from Natural Products with Potential Antidiabetic Activity. - A Systematic Review. Curr Diabetes Rev 14(1): 36-106.

NAHA PC, DAVOREN M, LYNG FM \& BYRNE HJ. 2010. Reactive Oxygen Species (ROS) Induced Cytokine Production and Cytotoxicity of PAMAM Dendrimers in J774A.1 Cells. Toxicol Appl Pharmacol 246(1-2): 91-99.

NAZARUK J \& BORZYM-KLUCZYK M. 2015. The Role of Triterpenes in the Management of Diabetes Mellitus and Its Complications. Phytochem Rev 14(4): 675-690.

NEMUDZIVHADI V \& MASOKO P. 2014. In Vitro Assessment of Cytotoxicity, Antioxidant, and Anti-Inflammatory Activities of Ricinus Communis (Euphorbiaceae) Leaf Extracts. Evid Based Complement Alternat Med 2014: 625961.

PETROVSKA B. 2012. Historical Review of Medicinal Plants' Usage. Pharmacogn Rev 6(11): 1-5.

PINGPINGLI P ET AL. 2015. LTB4 Promotes Insulin Resistance in Obese Mice by Acting on Macrophages Hepatocytes and Myocytes. Nat Med 21(3): 239-247.

PODDER B, JANG WS, NAM KW, LEE BE \& SONG HY. 2015. Ursolic Acid Activates Intracellular Killing Effect of Macrophages during Mycobacterium Tuberculosis Infection. J Microbiol Biotechnol 25(5): 738-744.

POLLIER J \& GOOSSENS A. 2012. Oleanolic Acid. Phytochemistry 77: 10-15.

POLONSKY WH \& HENRY RR. 2016. Poor Medication Adherence in Type 2 Diabetes: Recognizing the Scope of the Problem and Its Key Contributors. Patient Prefer Adherence 10: 1299-1307.

PROCACCINI C, JIRILLO E \& MATARESE G. 2012. Leptin as an Immunomodulator. Mol Aspects Med Molecular Aspects of Medicine 33(1): 35-45.

QUIAN W, LU H, LIU X, YIE S, XIANG J \& YAO Z. 2015. Study of Oleanolic Acid on the Estrodiol Production and the Fat Production of Mouse Preadipocyte 3T3-L1 in Vitro. Hum Cell 28(1): 5-13.

REILLY SM \& SALTIEL AR. 2017. Adapting to Obesity with Adipose Tissue Inflammation. Nat Rev Endocrinol 13(11): 633-643.

RENDRA E, RIABOV V, MOSSEL DM, SEVASTYANOVA T, HARMSEN MC \& SAAD B, ZAID H, SHANAK S \& KADAN S. 2017. Anti-Diabetes 
and Anti-Obesity Medicinal Plants and Phytochemicals. Springer International Publishing AG, 257 p.

SALTIEL AR \& OLEFSKY JM. 2017. "Inflammatory Mechanisms Linking Obesity and Metabolic Disease." J Clin Invest 127(1): 1-4.

SEO DY, LEE SR, HEO JW, NO MH, RHEE BD, KO KS, KWAK HB \& HAN J. 2018. Ursolic Acid in Health and Disease. Korean J Physiol Pharmacol 22(3): 235-248.

SHARMA H, KUMAR P, DESHMUKH RR, BISHAYEE A \& KUMAR S. 2018. Pentacyclic Triterpenes: New Tools to Fight Metabolic Syndrome. Phytomedicine 50: 166-177.

SILVA FSG, OLIVEIRA PJ \& DUARTE MF. 2016. Oleanolic, Ursolic, and Betulinic Acids as Food Supplements or Pharmaceutical Agents for Type 2 Diabetes: Promise or Illusion? J Agric Food Chem 64(15): 2991-3008.

THOMAS D \& APOVIAN C. 2017. Macrophage Functions in Lean and Obese Adipose Tissue. Metabolism 72: 120-143.

WANG X, CHEN Y, ABDELKADER D, HASSAN W, SUN H \& JUN LIU. 2015. Combination Therapy with Oleanolic Acid and Metformin as a Synergistic Treatment for Diabetes. J Diabetes Res 2015: 973287.

WANG XT, GONG Y, ZHOU B, YANG JJ, CHENG Y, ZHAO JG \& QI MY. 2018. Ursolic Acid Ameliorates Oxidative Stress, Inflammation and Fibrosis in Diabetic Cardiomyopathy Rats. Biomed Pharmacother 97(8): 1461-1467.

WHO. 2018. Obesity and Overweight. World Health Organization Fact Sheets. https://www.who.int/ news-room/fact-sheets/detail/obesity-and-overweight.

WU H \& BALLANTYNE CM. 2017. Skeletal Muscle Inflammation and Insulin Resistance in Obesity. J Clin Invest 127(1): 43-54.

YUAN H, MA Q, CUI H, LIU G, ZHAO X \& LI W. 2017. How Can Synergism of Traditional Medicines Benefit from Network Pharmacology? Molecules 22(1135): 1-19.

YUCHANG F, LUO N, KLEIN RL \& GARVEY WT. 2005. Adiponectin Promotes Adipocyte Differentiation, Insulin Sensitivity, and Lipid Accumulation. J Lipid Res 46: 1369-1379.

\section{SUPPLEMENTARY MATERIAL}

\section{Figure S1}

\section{Tables SI-SIV}

\section{How to cite}

BETANCUR LI, MUÑOZ DL, GUILLEN A, ECHEVERRI LF, BALCAZAR N \& ACíN S. 2021. Major triterpenoids from Eucalyptus tereticornis have enhanced beneficial effects in cellular models when mixed with minor compounds present in raw extract. An Acad Bras Cienc 93: e20201351. DOI 10.1590/0001-3765202120201351.
Manuscript received on October 14, 2020;

accepted for publication on November 18, 2021

\section{LAURA I. BETANCUR ${ }^{1}$}

https://orcid.org/0000-0001-6062-6775

DIANA L. MUÑOZ

https://orcid.org/0000-0001-8044-7117

\section{ALIS GUILLEN ${ }^{1}$}

https://orcid.org/0000-0001-8498-9378

\section{LUIS F. ECHEVERRI ${ }^{2}$}

https://orcid.org/0000-0002-9530-8395

NORMAN BALCAZAR ${ }^{1,3}$

https://orcid.org/0000-0002-1860-1176

\section{SERGIO ACÍN ${ }^{1,3}$}

https://orcid.org/0000-0001-7335-2865

${ }^{1}$ GENMOL Group/Sede de Investigación Universitaria, Cl. 62 \#52-59, University of Antioquia, 050010 Medellín, Antioquia, Colombia

${ }^{2}$ QOPN Group/Sede de Investigación Universitaria, University of Antioquia, Faculty of Exact and Natural Sciences, Cl. 62 \#52-59, 050010 Medellín, Antioquia, Colombia ${ }^{3}$ University of Antioquia, Faculty of Medicine, Cra. 51d \#62-29, Department of Physiology and Biochemistry, 050010 Medellín, Antioquia, Colombia

Correspondence to: Sergio Acín

E-mail:sergio.acin@udea.edu.co

\section{Author contributions}

Laura Isabel Betancur: Carried out the experiments, collected the data and wrote the manuscript.

Diana Lorena Muñoz and Alis Guillen: Carried out the experiments and collected the data. Luis Fernando Echeverri: Purified OBE100 and UAL. Norman Balcazar: Conceived, designed the experiments, supervised the project and wrote the manuscript. Sergio Acín: Conceived, designed the experiments, supervised the findings of this work and wrote the manuscript. All authors provided critical feedback and helped shape the research, analysis and manuscript.

\section{(cc) BY}

